\title{
Students' Perception towards Effectiveness of Master Level Health Education Curriculum in Semester System under Faculty of Education, TU
}

\author{
Deep Bahadur Adhikari \\ Central Department of Education, Tribhuvan University \\ Kirtipur, Nepal \\ Email: dip.bdr@gmail.com
}

DOI: $10.31364 / S C I R J / v 6 . i 7.2018 . P 0718558$

http://dx.doi.org/10.31364/SCIRJ/v6.i7.2018.P0718558

\begin{abstract}
For better teaching and effective learning, it is very essential to know the views of students about curriculum. The curriculum is designed for students, but the enrollment of students in the teaching leaning process is not less important in the field of academia. Tribhuwan University (TU) has delivered the Master level Health Education Curriculum in semester system. The purpose of this study is to present the effectiveness of curriculum and the perception of students towards it. It is hoped that the views of the students would be helpful for the improvement, design and formulation of new curriculum in future days. The students of third and fourth semester were taken as sample population. As a result, above eighty percent students expressed the relevancy and appropriateness of the curriculum. Interestingly, hundred percent students appreciated the teachers' competency and dedication. Above seventy percent students were found to be satisfied with applied teaching methods and materials, whereas about 40 percent students were dissatisfied with physical environment of the class as well as the department. About ten percent of the students had some complain about the evaluation system. No any further complaints were received with regards to discipline, attendance and participation in the class.
\end{abstract}

Index Terms-Curriculum, effectiveness, learning experiences, curriculum effectiveness, perception, teachers' competency, relevancy, appropriateness

\section{INTRODUCTION}

Curriculum refers to an educational plan incorporating a structured, developmentally appropriate series of intended learning outcomes and associated learning experiences for students, generally organized as a detailed set of course directions, strategies, lessons and related combinations of school or college based materials, contents and events (US Department, 2010)

Curricular effectiveness is the extent to which a curricular program and its implementation produce positive and curricular valid outcomes for students. Describing curricular effectiveness involves the identification and description of curriculum and its programmatic theory and stated objectives ;its relationship with; local state, or national standards; subsequent scrutiny of its program contents for comprehensiveness, accuracy and depth balance, engagement and timeliness and support for diversity and an examination of the quality, fidelity and character of its implementation components. Efficacy is also viewed as considering issues of cost, timeliness and resource availability relative to the measure of effectiveness for comprehensiveness (National Research Council 2004).

Health education is an integral to the primary mission of schools and universities. It provides young people with the knowledge and skills they need to become successful learners and healthy and productive adults. Health education is a fundamental part of an overall school health program. Increasing the number of schools that provide health education on key health problems facing by young people is a critical health objective for creating and improving healthy nation. (National Research Council 2004)

Health instruction in schools or universities is shaped, in large part, by the health education curriculum. An effective curriculum provides opportunities for students to validate positive health-promoting beliefs, intentions, and behaviors. It provides opportunities for students to assess their vulnerability to health problems, actual risk of engaging in harmful health behaviors, and exposure to unhealthy situations. Choosing or developing the best possible health education curriculum is a critical step in ensuring that health education is effectively promoting healthy behaviors. A health education curriculum is the primary means through which schools deliver health education

Numbers of organizations have identified specific interventions and curricula they have determined to be exemplary, promising, or effective in improving students' health-related behaviors However, these curricula do not always meet the needs because the number of currently identified health curricula with evidence of effectiveness is limited. Schools/colleges sometimes cannot implement these curricula exactly as they were originally assumed due to many reasons. Sometime curriculum may not be appropriate or acceptable based on community values, and may not be feasible due to instructional time limitations, excessive costs, or burdensome in professional development requirements.

For six decades in Nepal, health education curriculum has been implementing in primary to secondary level in each grade as compulsory or optional subjects and whereas in universities, health education curriculum has been introduced as compulsory subject in the I.Ed and B.Ed since its beginning days and till now it is getting continuity in the bachelor and master level of health education department under the faculty of Education (Tribhuvan University) and its affiliated 
campuses. Now college of education is under the Faculty of education (TU), and continually has been implementing health and physical education curriculum in the campuses under the Faculty of education of different Universities. In 2069 BS, Tribhuwan University launched semester system in master level of health education curriculum and already two batches were passed out. Rest of other TU affiliated campuses are approaching for this. As a newly promulgated system, it is necessary to listen the voice of students and collect their views for the further development. Concerning the today's need, this study has been carried out to highlights the perspective of students, challenges and possibilities of curriculum implementation. Since 2069BS TU has been running semester system in master level of health education curriculum and already two batches have been passed out. Other campuses of Kathmandu are also in the process for applying this system. It is the time of evaluation about its implementation that is why it's strong and weak points could be pointed out and which will contribute to increase and improve the program. In this context this paper tries to high light about the perception of the students towards the effectiveness of this program.

The objective of this study was to identify the meaningfulness and effectiveness of the program through the perspective of the students regarding the availability of physical facilities, use of teaching materials, methods, class discipline, students' participation, teachers' dedication, competence and evaluation procedure.

\section{RESEARCH METHODOLOGY}

This research was designed on the basis of descriptive and quantitative in nature and based on the primary sources of data. The study covered the sample of 56students having studied in M.Ed. $3^{\text {rd }}$ and fourth semester in health education by applying census method. Questionnaire was used as the tools of this study. Data were analyzed using simple statistic like mean, percentage and ratio.

\section{ANALYSIS AND INTERPRETATION OF RESULTS}

\section{Relevancy and appropriateness of the curriculum}

Relevancy of the curriculum indicates the objectives of the curriculum as per the needs of the society as well as the contents and activities according to objectives of the curriculum should be evaluated. Likewise appropriateness evaluates the need of target group and time of program implementation. In this study, responding the question about relevancy of curriculum more than 80 percent students expressed positive view and rest 20 percent students expressed relevancy and appropriateness is poor. Above data indicates there is need to review the curriculum and weak points should be corrected.

TABLE I. RELEVANCY AND APPROPRIATENESS OF THE CURRICULUM

\begin{tabular}{|l|c|c|}
\hline \multicolumn{1}{|c|}{ Level } & No & Percent \\
\hline Very good & 02 & 03.57 \\
\hline Good & 16 & 28.57 \\
\hline Satisfactory & 28 & 50.00 \\
\hline Poor & 10 & 17.85 \\
\hline Total & $\mathbf{5 6}$ & $\mathbf{1 0 0}$ \\
\hline
\end{tabular}

Source: Field Survey 2017

\section{Dedication and competency of the teachers}

Teachers' dedication and competency plays great role to improve quality of education. A competent teacher can impart knowledge to the students effectively. Regarding the competency and dedication of the health education teacher 100 percent the students reported positively or no one reported poor competency and dedication of the teachers (Table 2).

TABLE II. STUDENTS PERCEPTION TOWARDS DEDICATION AND COMPETENCY OF THE TEACHERS

\begin{tabular}{|l|c|c|}
\hline \multicolumn{1}{|c|}{ Level } & No & Percent \\
\hline Very good & 04 & 7.14 \\
\hline Good & 36 & 64.28 \\
\hline Satisfactory & 16 & 28.57 \\
\hline Poor & 0 & 00 \\
\hline Total & & $\mathbf{1 0 0}$ \\
\hline
\end{tabular}

Source: Field Survey 2017

\section{Use of teaching materials}

Teaching materials are used to make teaching learning more effective and interesting. It makes students to understand subject matter in simple and interesting way.

TABLE III. USE OF TEACHING MATERIALS

\begin{tabular}{|l|c|c|}
\hline Level & No & Percent \\
\hline Very good & 02 & 3.57 \\
\hline Good & 18 & 32.14 \\
\hline Satisfactory & 22 & 39.28 \\
\hline Poor & 14 & 25.00 \\
\hline Total & $\mathbf{5 6}$ & $\mathbf{1 0 0}$ \\
\hline
\end{tabular}

Source: Field Survey 2017

Regarding the use of teaching materials in the health education class of semester system3.57 percent students reported very good, 32.14 good 39.28 reported satisfactory and 25 percent students blamed teaching materials were poor.

\section{Use of teaching methods}

Wesely defines teaching method as a systematic procedure adopted for the attainment of specific objectives. It is an art of communicating information among the students or among the people. It is the way or path followed in imparting knowledge with the aim of securing the best possible educational results (Bhatia and Bhatia).Best teaching methods certainly contributes to better educational achievements. In this study there was a question about the teaching methods to the students the answer is presented in the table 4.

TABLE IV. STUDENTS' PERCEPTION TOWARDS USE OF TEACHING METHODS

\begin{tabular}{|l|c|c|}
\hline \multicolumn{1}{|c|}{ Level } & No & Percent \\
\hline Very good & 02 & 03.57 \\
\hline Good & 24 & 42.85 \\
\hline Satisfactory & 24 & 42.85 \\
\hline Poor & 06 & 10.71 \\
\hline Total & $\mathbf{5 6}$ & $\mathbf{1 0 0}$ \\
\hline
\end{tabular}

Source: Field Survey 2017 
Table no 4 shows about 90 percent of the students were satisfied with the applied teaching methods in the class and only 10.71 percent students reported they were not satisfied with used teaching methods. It indicates most of the students had appreciated the used teaching methods as good.

\section{Physical facilities in the classroom}

Class size, light, ventilation, furniture, and board, multimedia, drinking water are more essential physical facilities in the class that contribute for better teaching learning environment. Regarding this question about 40 percent students reported that physical facilities in the classroom were poor (table 5).

TABLE V. STUDENTS' PERCEPTION TOWARDS PHYSICAL FACILITIES IN THE CLASS ROOM

\begin{tabular}{|l|c|c|}
\hline \multicolumn{1}{|c|}{ Level } & No & Percent \\
\hline Very good & 00 & 00.00 \\
\hline Good & 02 & 03.57 \\
\hline Satisfactory & 32 & 57.14 \\
\hline Poor & 22 & 39.28 \\
\hline Total & $\mathbf{5 6}$ & $\mathbf{1 0 0}$ \\
\hline
\end{tabular}

Source: Field Survey 2017

From this result it can be said that physical facilities in the classroom should be improved.

\section{Discipline in the classroom}

Not only for the students' discipline is important in every aspects of life. If the students are not disciplined teaching learning may not be effective and educational objectives may not be achieved. Answering the questions about discipline in the classroom as well as in the department more than 95 percent students replied discipline was good. (Table6). While researcher observed the class size found standard. There were less than 30 students in each class and all students were listening and participating in activities.

TABLE VI. STUDENTS' PERCEPTION TOWARDS DISCIPLINE IN THE CLASSROOM

\begin{tabular}{|l|c|c|}
\hline \multicolumn{1}{|c|}{ Level } & No & Percent \\
\hline Very good & 06 & 10.71 \\
\hline Good & 40 & 71.42 \\
\hline Satisfactory & 08 & 14.28 \\
\hline Poor & 02 & 03.57 \\
\hline Total & $\mathbf{5 6}$ & $\mathbf{1 0 0}$ \\
\hline
\end{tabular}

Source: Field Survey 2017

\section{Evaluation system and results}

Evaluation is the determination of degree to which an educational programs goals are achieved (Tyler).It is the process of gathering and interpreting evidences of changes in the behavior of the students as they perform through school.

TABLE VII. EVALUATION SYSTEM

\begin{tabular}{|l|c|c|}
\hline \multicolumn{1}{|c|}{ Level } & No & Percent \\
\hline Very good & 6 & 10.71 \\
\hline Good & 20 & 35.71 \\
\hline
\end{tabular}

\begin{tabular}{|l|c|c|}
\hline Satisfactory & 26 & 46.42 \\
\hline Poor & 4 & 07.14 \\
\hline Total & $\mathbf{5 6}$ & $\mathbf{1 0 0}$ \\
\hline
\end{tabular}

Source: Field Survey 2017

This study result indicates that more than 90 percent of the students reported used evaluation system was good and only about 7 percent students were less satisfied with the evaluation system. From the above result it indicates that applied evaluation system is satisfactory.

\section{Attendance and participation of the students and teachers} Students' attendance and participation in the class is important factor for teaching and learning. A question was asked to the class teachers about the attendance and participation of the students all of them reported that more than 90 percent students were regular and actively participated. Even the classes were regularly conducted by the concerned teachers.

\section{Most impressive problems of the students}

There was a question to the students about what is the most impressive problem in your class? Answering this question about 40 percent students replied physical facilities was the most impressive problem and about 15 percent indicated impracticable curriculum was the impressive problem, likewise 10/10 percent teaching methods and teaching materials were the pressing problems. From the above data it can be said that physical facilities was the most pressing problem (Table 8).

TABLE VIII. BURNING/IMPRESSIVE PROBLEMS

\begin{tabular}{|l|c|c|}
\hline \multicolumn{1}{|c|}{ Problems } & No & Percent \\
\hline Physical facilities & 22 & 39.28 \\
\hline Teaching materials & 06 & 10.71 \\
\hline Library facilities & 06 & 10.71 \\
\hline Teaching methods & 06 & 10.71 \\
\hline Evaluation & $\mathbf{0 6}$ & $\mathbf{1 0 . 7 1}$ \\
\hline Fee & $\mathbf{0 2}$ & $\mathbf{3 . 5 7}$ \\
\hline Curriculum Fee & $\mathbf{0 8}$ & $\mathbf{1 4 . 2 8}$ \\
\hline Total & $\mathbf{5 6}$ & $\mathbf{1 0 0}$ \\
\hline
\end{tabular}

Source: Field Survey 2017

\section{CONCLUSIONS}

As its prior expectation, the study achieved the satisfactory result regarding to the implementation of health education curriculum with the availability of factors such as physical facilities, use of teaching materials, methods, class discipline, students' participation, teachers' dedication, competence and evaluation procedure. The study revealed the inadequacy of necessary equipment and service. For the further enhancement of academic process and the high performance of students, the study recommends further improvement of infrastructures, modification of teaching methods, availability of materials/equipment, active enrollment of students and promotion of own creativity and innovativeness activities in the class.

\section{REFERENCES}

[1] "3 Framework for Evaluating Curricular Effectiveness "National Research Council.2004.On 
Curricular Effectiveness: Judging the quality of K-12 Mathematics Evaluation .Washington DC: The National Academic press.doi:0.17226/11025.

[2] "Content Analysis "National Research Council 2004 On Evaluating Curricular Effectiveness: Judging the quality of $K$ 12 Mathematics Evaluation .Washington DC: The National Academic press.doi:0.17226/11025.

[3] John W. Best \& James V. Khan (2003) Research in Education (7th Ed.). Asoke K. Ghosh Prentice hall of India New Delhi.

[4] Kafle B.D \& Etal (2067BS) Educational Planning Sun light Publication, Kirtipur

[5] Master level Semester system health education curriculum 2067, Kirtipur FOE Dean's Office,TU.
[6] Master level Semester system health education curriculum, TU (2070). Kirtipur FOE Dean's Office, TU.

[7] Master level Yearly system health education curriculum TU, Kirtipur FOE Dean's Office,TU.

[8] Neupane, I.P (2058) Methods of Teaching Population Education, Vidhyarthi Ppustak Bhotahiti

[9] Park. \& Park (2013) A text Book of Preventive and Social medicine, Jabalpur; MS. Banarasidas Bhanot,.

[10] U.S. Department of Health and Human Services. Healthy People 2020: Early and Middle Childhood. Washington, DC: HealthyPeople.gov; 2010. 